\title{
BENDING BEHAVIOR OF COLD-FORMED STEEL-CONCRETE COMPOSITE FLOORS
}

\author{
Xin-mei Yao ${ }^{1}$, Xu-hong Zhou ${ }^{1,2,3}$, Yu Guan ${ }^{1}$, Yu Shi ${ }^{2,3, ~}{ }^{*}$ and Zi-qi He ${ }^{2,3}$ \\ ${ }^{1}$ College of Civil Engineering, Chang'an University, Xi'an, China \\ ${ }^{2}$ School of Civil Engineering, Chongqing University, Chongqing, China \\ ${ }^{3}$ Key Laboratory of New Technology for Construction of Cities in Mountain Area (Ministry of Education), Chongqing University, Chongqing, China \\ *(Corresponding author: E-mail: shiyu7811@163.com)
}

\section{A B S T RA C T}

In cold-formed steel framing constructions, cold-formed steel-concrete composite floors built with concrete slabs and cold-formed steel joists are a common floor system. To investigate the bending behavior of such a floor system, two floor specimens with alternative slab materials were evaluated. The test results indicated that varying the slab materials had no significant influence on the ultimate bending capacity; however, the stiffness of the composite floor with a concrete slab was much higher than that of the floor with a gypsum-based self-leveling underlayment slab. A finite element model was developed and validated with the test results to simulate the bending behavior of the floors using the ANSYS finite element software. Parametric investigations were conducted through the verified finite element models. The results showed that the web depth-to-thickness ratio, span-to-depth ratio of the joist, and steel strength significantly affected the ultimate bending capacity of the composite floors, whereas the effects of screw spacing and concrete slab thickness were negligible. Finally, a simplified method was proposed to evaluate the ultimate moment capacity of cold-formed steelconcrete composite floors. The results obtained from the proposed method were validated by both experimental and numerical investigations of two full-scale cold-formed steel-concrete composite floors built with concrete slabs and coldformed steel joists.

\section{ART I C L E H IS T O R Y}

$\begin{array}{ll}\text { Received: } & \text { 10 October } 2018 \\ \text { Revised: } & \text { 28 April } 2019 \\ \text { Accepted: } & \text { 01 May } 2019\end{array}$

\section{K E Y W O R D S}

Composite floor;

Bending behavior;

Cold-formed steel;

Experimental study;

Numerical analysis;

Simplified method

\section{Introduction}

It is well known that floor systems of buildings play a key role in bearing vertical loads and transferring them to wall panels and foundations. Coldformed steel (CFS) composite floor systems comprising CFS joists and concrete composite slabs have been used extensively in CFS framing because of their high strength-to-weight ratio and non-combustibility. For example, CFS-concrete composite floors have been employed in the "Poly Canyon Village" project in California [1]. Although the mechanical performance of hot-rolled steel and concrete composite beams has been investigated comprehensively, research on the behavior of CFS-concrete composite floors due to the thinness of CFS members, which is different from that of hot-rolled steel, is scarce

Extensive experimental studies have been conducted on the composite action of CFS and concrete. Based on push-out tests of different shear connectors and bending tests of full-scale CFS-concrete composite beams, Hanaor [2] concluded that the ductility and capacity of composite beams with shear connectors were higher than those of the design assumptions. Experimental investigations conducted by Lakkavalli et al. [3] and Irwan et al. $[4,5]$ indicated the advantages of installing shear transfers between CFS and concrete. It can be concluded that shear transfers employed within composite beams and floors are crucial for the composite action between the joists and concrete owing to the resistance slipping between the CFS and concrete slab, and hence, result in an improved loading moment capacity of the system. Therefore, a different type of shear transfer was used in the CFS-concrete composite floors in this study.

In recent years, innovative and practical floor systems have been investigated for determining the bending behavior of composite floor systems. A new composite beam system built with back-to-back CFS joists, reinforced concrete slab on corrugated cold-formed metal, and shear connectors was developed by Hsu et al. [6]. It exhibited better bending behavior for strength and ductility compared with non-composite beams. Four-point bending tests were performed on composite CFS and wood-based flooring systems by Kyvelou [7], and the benefits of the composite action in CFS flooring systems were first illustrated through practical exploitation. However, the bending behavior of a CFS-concrete composite floor comprising a CFS frame and concrete slab has not been studied, and research on CFS-concrete composite floors with different types of shear transfer, such as the $\mathrm{Z}$ tab shear transfer, is insufficient. In addition, the influence of slab materials, such as gypsum-based self-leveling underlayment (GSU) and fine aggregate concrete (FAC), on the performance of composite floors needs to be explored.

In this study, an experimental method for investigating the bending behavior of a CFS-concrete composite floor system is presented. Moreover, a numerical simulation approach is provided to analyze the influence of some parameters such as the web depth-to-thickness ratio and span-to-depth ratio of the joist, screw spacing, concrete slab thickness, and steel strength on the bending performance of such floor system. Furthermore, a simplified method for the calculation of the ultimate moment capacity of the floor is presented to provide a practical design reference and a calculation method for engineers involved in the design of CFS-concrete composite floors. The structure of this paper is as follows. After the introduction, section 2 presents the details, results, and analysis of the tests. Section 3 discusses the established finite element (FE) model and the analysis of the influences of key parameters on the bending performance of the CFS-concrete floor. In section 4, a simplified method for calculating the ultimate moment capacity of composite floors is presented. Finally, section 5 provides the primary conclusions.

\section{Bending test program}

\subsection{Test specimen}

The objective of this experimental study is to investigate the bending behavior of a CFS-concrete composite floor with different slab materials. The configurations of two composite floor specimens are summarized in Table 1. As indicated in the table, the slab material of BM-1 is GSU, whereas that of BM-2 is FAC. The floor configuration of BM-1 is illustrated in Fig. 1, and the width and length of BM-1 were $0.8 \mathrm{~m}$ and $3.6 \mathrm{~m}$, respectively. The floor specimen comprises two primary parts: the CFS frame and composite slab. Fig. 1 shows that the $\mathrm{CFS}$ frame consists of three $\mathrm{C}$-shape joists with dimensions of $254 \times 40 \times 13 \times 1.5 \mathrm{~mm}$ spaced at $400 \mathrm{~mm}$ on center, and two U-shape tracks with dimensions of $254 \times 40 \times 1.5 \mathrm{~mm}$ connected to the flange at each end of the joists through self-tapping screws with a diameter of $4.8 \mathrm{~mm}$ (ST4.8 screws). A $50 \times 1.0 \mathrm{~mm}$ (width $\times$ thickness) steel strap was fastened to the bottom flanges at the midspan of the joists using ST4.8 screws to avoid lateral torsion of the joists. Moreover, Fig. 1 shows that web stiffeners were fastened to both ends of the CFS joists through six ST4.8 screws to resist the web crippling of the joists at the supports. 
The composite slab comprises a $0.75 \mathrm{~mm}$ thick YX-14-63-820 shallow CFS form deck, a $40 \mathrm{~mm}$ thick GSU solid slab, and Z tab shear transfers as shown in Fig. 2. As indicated in Fig. 3, the CFS form deck was connected to the joists through hexagon-head self-tapping screws with diameters of $5.5 \mathrm{~mm}$ (ST5.5 screws) spaced at $126 \mathrm{~mm}$ and $252 \mathrm{~mm}$ along the perimeter and in the field of the CFS form deck, respectively. Additionally, the $\mathrm{Z}$ tab shear transfers were fastened to the CFS form deck spaced at $252 \mathrm{~mm}$ along the length of the joists using ST5.5 screws. The GSU was poured on the CFS form-deck, which was brushed with a layer of interfacial agent to enhance the bond capacity between the GSU slab and the CFS form deck.
Table 1

Description of composite floor test specimens

\begin{tabular}{|c|c|c|c|}
\hline Specimen & Material of slab & $\begin{array}{l}\text { Configuration of } \\
\text { shear transfer }\end{array}$ & Details of steel members (mm) \\
\hline BM-1 & GSU & $\begin{array}{l}\mathrm{Z} \text { tab shear } \\
\text { transfer+ }\end{array}$ & 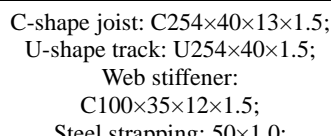 \\
\hline BM-2 & FAC & & $\begin{array}{l}Z \text { tab shear transfer: } 20 \times 15 \times 1.5 \text {; } \\
\text { CFS form-deck: } Y X-14-63-820\end{array}$ \\
\hline
\end{tabular}

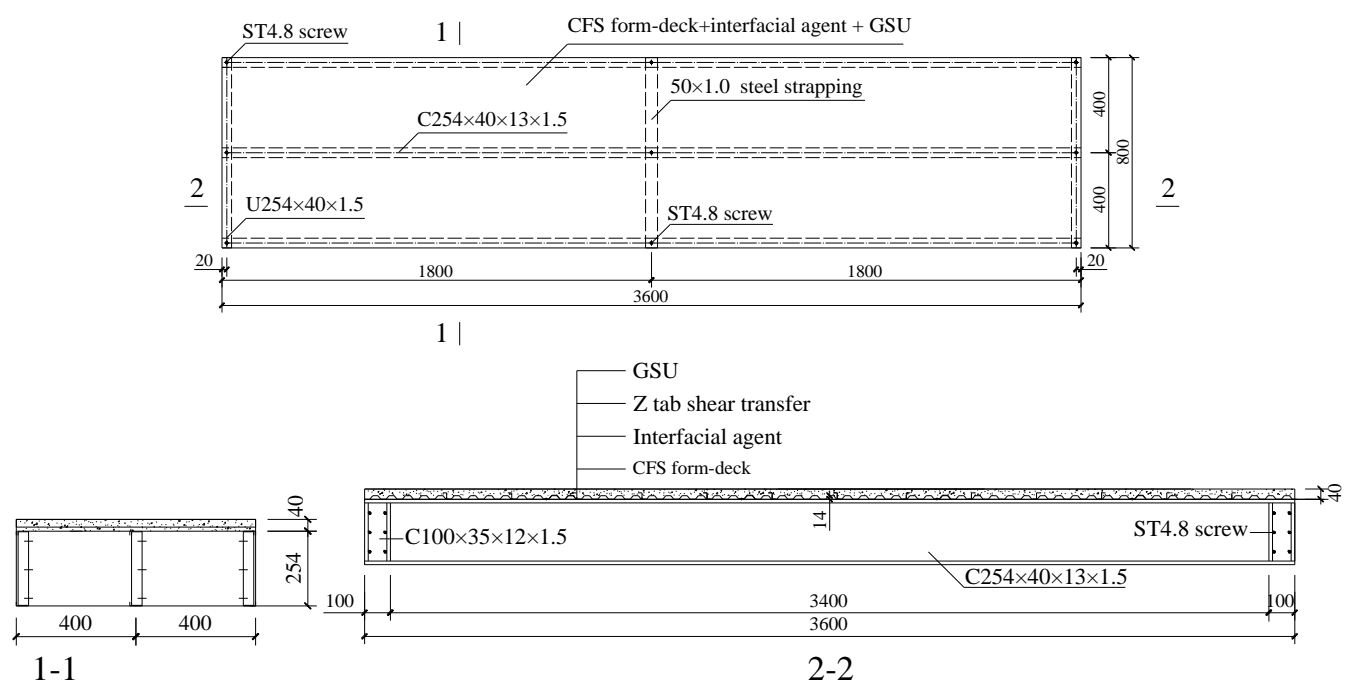

Fig. 1 Dimensions of specimen BM-1 (all dimensions in mm)

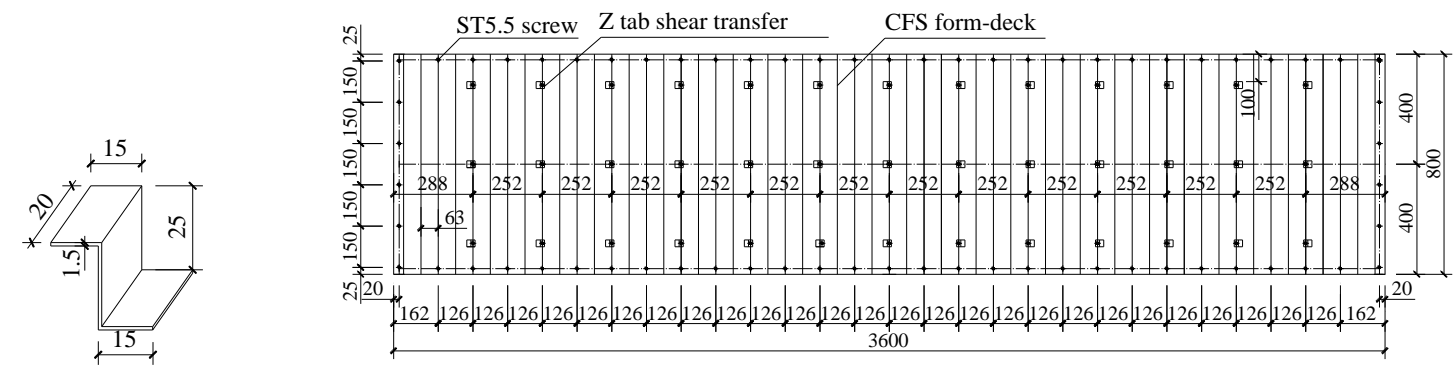

Fig. $2 \mathrm{Z}$ tab shear transfer (all dimensions in $\mathrm{mm}$ )

Fig. 3 Connection between $\mathrm{Z}$ tab shear transfer and CFS form-deck (all dimensions in mm)

\subsection{Material properties}

Table 2 lists the mechanical properties of CFS materials in the floor specimens tested following GB/T 228.1 [8], where $E_{\mathrm{s}}$ is the elastic modulus of steel. The average steel thickness of the CFS joists and form-deck were 1.5 $\mathrm{mm}$ and $0.75 \mathrm{~mm}$, respectively. For the CFS joists and tracks, the average yield and tensile strengths were $318.4 \mathrm{MPa}$ and $369.6 \mathrm{MPa}$, respectively, and the steel elastic modulus and Poisson's ratio were $2.09 \times 10^{5} \mathrm{MPa}$ and 0.3, respectively. For the CFS form-deck, the average yield and tensile strengths were $356.3 \mathrm{MPa}$ and $438.6 \mathrm{MPa}$, respectively, and the steel elastic modulus and Poisson's ratio were $2.00 \times 105 \mathrm{MPa}$ and 0.3 , respectively. The properties of concrete tested according to GB 50081 [9] are presented in Table 3, where $E_{\mathrm{c}}$ is the elastic modulus of concrete. The average compressive strength of 100 $\times 100 \times 100 \mathrm{~mm}$ GSU cubes at 28 days was $33.7 \mathrm{MPa}$ with an elastic modulus of $2.17 \times 10^{4} \mathrm{MPa}$, while it was $31.17 \mathrm{MPa}$ with an elastic modulus of 3.0 $\times 10^{4} \mathrm{MPa}$ for FAC cubes. The ultimate shear forces were $7.56 \mathrm{kN}$ and $9.30 \mathrm{kN}$ for the ST4.8 and ST5.5 screws, respectively.

Table 2

Properties of CFS

\begin{tabular}{ccccc}
\hline Material & Thickness $(\mathrm{mm})$ & Average yield strength $(\mathrm{MPa})$ & Average tensile strength $(\mathrm{MPa})$ & Elastic modulus $E_{\mathrm{s}} \times 10^{5}(\mathrm{MPa})$ \\
\hline CFS joists and tracks & 1.5 & 318.4 & 369.6 & 2.09 \\
CFS form-deck & 0.75 & 356.3 & 438.6 & 2.00 \\
\hline
\end{tabular}

Table 3

Properties of concrete

\begin{tabular}{ccccc}
\hline Material & Cube size $(\mathrm{mm})$ & Density $\left(\mathrm{kg} / \mathrm{m}^{3}\right)$ & Average cube compressive strength $(\mathrm{MPa})$ & Elastic modulus $E_{\mathrm{c}} \times 10^{4}(\mathrm{MPa})$ \\
\hline GSU & $100 \times 100 \times 100$ & 1969 & 33.70 & 2.17 \\
FAC & $100 \times 100 \times 100$ & 2077 & 31.17 & 3.0 \\
\hline
\end{tabular}




\subsection{Test setup}

Fig. 4 illustrates the test setup of the investigated composite floor, in which steel frames bolted to the concrete ground were used to support the floor specimens. The specimen was simply supported on hinge supports at either end of the joists. Steel plates were placed under the U-shaped tracks to prevent excessive concentrated stress. A hydraulic jack was used monotonically on the floor specimens using spreader beams with four concentrated forces for simulating a uniform gravity loading, as illustrated in Fig. 4(a). Before the tests, the expected ultimate load of the floors was calculated in accordance with the method proposed by Chien [10] to be approximately $120 \mathrm{kN}$. A load of $2.5 \%$ of the expected ultimate load was applied at $3 \mathrm{kN}$ per step until the ultimate capacity was reached. Subsequently, a load of $1 \mathrm{kN}$ per step was applied until failure occurred. Each step lasted for 3 min. The TDS-602 data acquisition system was used to record the applied load and displacements.

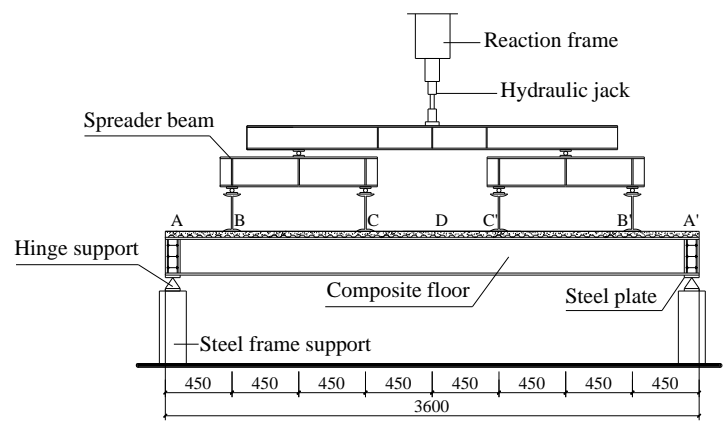

(a) Loading system

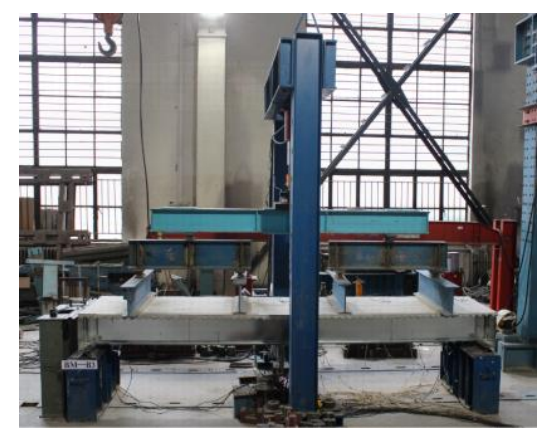

(b) Photograph of test setup

Fig. 4 Test setup of floor specimens

\subsection{Experimental results and discussion}

The BM-1 and BM-2 specimens were tested to investigate the bending behavior of the composite floor and explore the influence of the slab material on the bending performance of the composite floors. The failure characteristics, ultimate load, corresponding deflection of floors, and load-deflection curves are presented as follows.

\subsubsection{Failure characteristics}

Both specimens demonstrated similar failure characteristics in the tests. Here BM-1 was used as an example to illustrate the failure modes. When the applied load was approximately $53 \%$ of the ultimate load, webs of the boundary joists displayed shear buckling, as illustrated in Fig. 5(a). Furthermore, screw tilting was observed as illustrated in Fig. 5(b). When the load applied was $77 \%$ of the ultimate load, cracks were observed on the GSU slab. At the ultimate load, the specimens demonstrated disengagement of the CFS form-deck from the concrete slab on both end supports as shown in Fig. 5(c), torsional deformation of the joist webs as shown in Fig. 5(d), distortional buckling of the joists at the loading point (Fig. 5(e)), and bending deformation of the steel strapping as shown in Fig. 5(f).

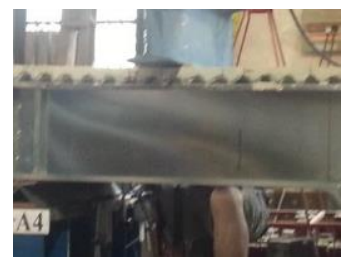

(a) Shear buckling of joist web

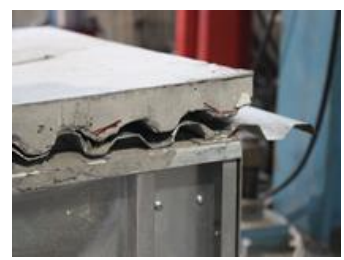

(c) Disengagement of CFS form-deck from concrete slab

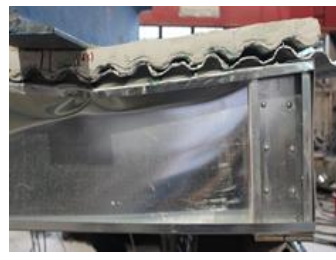

(e) Distortional buckling of joist at loading point

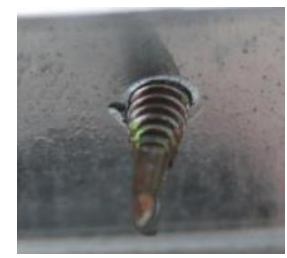

(b) Screw tilting

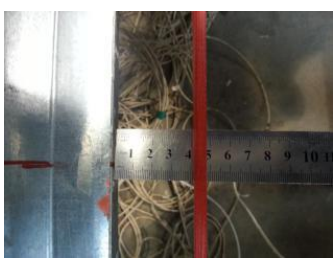

(d) Torsional deformation of joist web

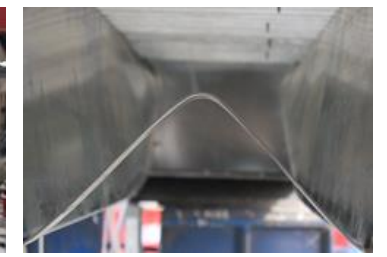

(f) Bending deformation of steel strapping
Fig. 5 Failure characteristics of BM-1

In the initial imperfections of the specimens before the tests, full-length cracks on the $\mathrm{Z}$ tab shear transfers along the floor length were observed. These were caused by the relative thinness of the concrete slab and abreast the regular arrangement of the $\mathrm{Z}$ tab shear transfers, thus weakening the bonding mechanism between the concrete slab and CFS form-deck, and consequently reducing the bending capacity of the composite floors. Therefore, a staggered arrangement of the $\mathrm{Z}$ tab shear transfers was suggested. In addition, the shear force between the concrete slab and CFS form-deck was transferred through the $\mathrm{Z}$ tab shear transfers and the interfacial agent; however, when the load was small, the lower shear resistance of the interfacial agent resulted in the earliest bond-slip failure between the concrete slab and CFS form-deck, from the support edge to the first row of the $\mathrm{Z}$ tab shear transfers. Subsequently, the bond-slip failure reduced at a distance closer to the loading point because of the large friction between the concrete slab and CFS form-deck resulting from the large compression at the loading point. With increasing applied load, the concrete slab failed at the loading point. This is attributable to the bond-slip failure occurring in the concrete slab, which hindered its operation with the CFS joists. Furthermore, the failure characteristics of the joists were overall bending deformation, torsional deformation, and interactive buckling of compressive CFS plate members.

\subsubsection{Ultimate load}

Table 4 presents the ultimate load $P_{\mathrm{u}}$ and the corresponding midspan vertical displacement $\Delta_{\mathrm{u}}$. As shown, BM-2 showed only a $2.8 \%$ increase in the ultimate load over BM-1, whereas the midspan vertical displacements of the central and boundary joists of BM-2 reduced by $30.6 \%$ and $27.4 \%$, respectively, compared with those of BM-1. The results demonstrated that the change in slab material had little influence on the ultimate load, but affected the flexural stiffness of the composite floors significantly.

Table 4

Test results

\begin{tabular}{cccc}
\hline Specimen & Location & $P_{\mathrm{u}}(\mathrm{kN})$ & $\Delta_{\mathrm{u}}(\mathrm{mm})$ \\
\hline \multirow{2}{*}{ BM-1 } & Central joist & \multirow{2}{*}{113.06} & 25.94 \\
& Boundary joist & & 30.37 \\
\multirow{2}{*}{ BM-2 } & Central joist & \multirow{2}{*}{116.32} & 17.98 \\
& Boundary joist & & 22.05 \\
\hline
\end{tabular}


A comparison of the load-deflection curves of BM-1 and BM-2 is illustrated in Fig. 6. As shown, the stiffness of BM-2 (with an FAC slab) was generally higher than that of BM-1(with a GSU slab). Furthermore, the specimens exhibited ductile failure rather than brittle failure. Fig. 7 illustrates the difference between the boundary and central joists of the composite floors. As shown in Fig. 7(a), the initial stiffness of the boundary and central joists of BM-1 was almost equal. However, when a load of $50 \mathrm{kN}$ was applied, the stiffness of the boundary joist decreased compared to that of the central joist; consequently, the deformation of the boundary joist was larger than that of the central joist with increasing load. Regarding BM-2, as shown in Fig. 7(b), the stiffness of the central joist was larger at first compared to that of the boundary joist. When a load of $100 \mathrm{kN}$ was applied, the stiffness degradation of the boundary joist was more evident than that of the central joist. As indicated in Table 4, the ultimate vertical deflection of the boundary joist was $5 \mathrm{~mm}$ larger than that of the central joist. This is attributable to the steel strapping that is transferring symmetric constraints from the two boundary joists to the central joist, thereby restricting the torsional and vertical deformations of the central joist.

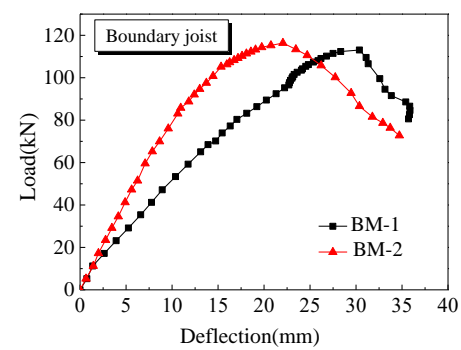

(a) Boundary joist

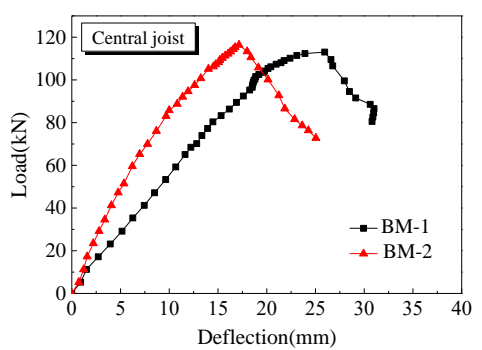

(b) Central joist

Fig. 6 Comparison of the load-deflection curves of BM-1 and BM-2

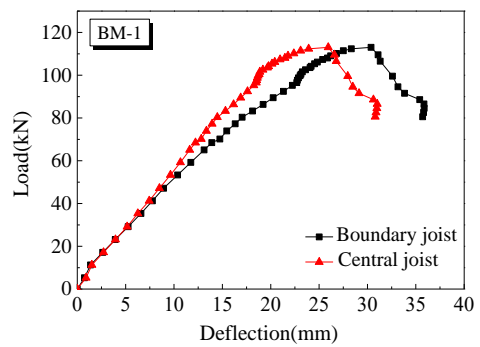

(a) BM-1

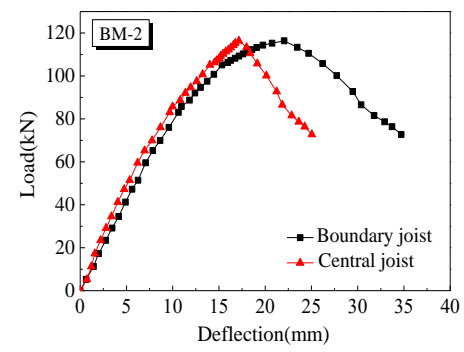

(b) BM-2

Fig. 7 Comparison of the load-deflection curves of boundary joist and central joist
Based on the failure characteristics of the concrete slab and the CFS joists of the specimens, the bending capacity of the composite floors is influenced by many factors, such as joist size, screw spacing, thickness of concrete slab, and steel strength. Therefore, the following analysis is based on specimen BM-1, and the influence of key parameters, including the web depth-to-thickness ratio, span-to-depth ratio of the joist, screw spacing, and steel strength, on the bending capacity of the CFS-concrete composite floor system, are investigated through numerical simulations.

\section{Nonlinear FE analysis}

\subsection{Verification of FE method}

The tested floors were simulated by the ANSYS FE software [11]. In the FE models, element shell181 was selected to simulate the steel members, as shown in Fig. 8(a). Element solid65 was found to be suitable for simulating the concrete slab. The self-tapping screws between the CFS joists and CFS formdeck were simulated by element beam188, as shown in Fig. 8(a). Except for the screws connecting the CFS joists and CFS form-deck, screw connections such as those between the joists and tracks, joists and web stiffeners, joists and steel strapping, and tracks and CFS form-deck, were simulated by coupling the two nodes at the screw connection and constraining the translation in the three degrees of freedom in the $x, y$, and $z$ directions, because these connections exhibited no obvious failure features, as shown in Fig. 8(a). The overall model of the specimen is shown in Fig. 8(b). The contact pair (element target170 and element target174) was constructed by using the surface-to-surface contact elements for modeling the contact behavior such as for the contact between concrete slab and corrugated metal deck. Boundary conditions and loads were applied as shown in Fig. 8(b). The displacements along the $x$ and $y$ directions at the left support and along the $x, y$, and $z$ directions at the right support were constrained. Uniformly distributed line loads were applied at the locations where the distribution beams were arranged, as illustrated in Fig. 8(b). The constitutive relation of the CFS used in the FE model was determined based on the test results.

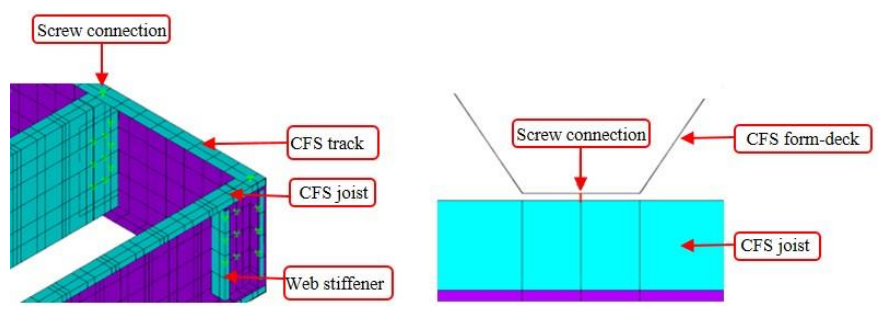

(a) Screw connection

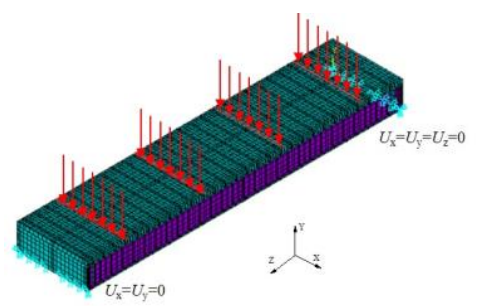

(b) Boundary conditions and loads of the specimen

Fig. 8 Finite element model of composite floor

Table 5 presents the comparison of the test results and FE analysis results on the ultimate bearing capacities and the corresponding deformations. In Table $5, P^{*}{ }_{\mathrm{u}}$ is the ultimate load obtained in FE analysis and $\Delta^{*}{ }_{\mathrm{u}}$ is the midspan vertical displacement corresponding to the ultimate load obtained FE analysis. The ultimate capacities of BM-1 and BM-2 predicted by the FE models were only $2 \%$ and $3 \%$ higher than those obtained from tests, respectively. Generally, the FE results agree strongly with the experimental results, and further parametric investigations can be conducted using the validated FE models. 
Table 5

Comparisons of finite element analysis and test results of specimens

\begin{tabular}{ccccccc}
\hline \multirow{2}{*}{ Specimen } & \multicolumn{3}{c}{ Ultimate bending capacity $(\mathrm{kN})$} & \multicolumn{3}{c}{ Deflection $(\mathrm{mm})$} \\
\cline { 2 - 7 } & $P_{\mathrm{u}}$ & $P^{*}{ }_{\mathrm{u}}$ & $P^{*}{ }_{\mathrm{u}} / P_{\mathrm{u}}$ & $\Delta_{\mathrm{u}}$ & $\Delta^{*}{ }_{\mathrm{u}}$ & $\Delta^{*}{ }_{\mathrm{u}} / \Delta_{\mathrm{u}}$ \\
\hline BM-1 & 113.06 & 115.79 & 1.02 & 25.96 & 24.93 & 0.96 \\
BM-2 & 116.36 & 119.84 & 1.03 & 22.05 & 21.87 & 0.99 \\
\hline
\end{tabular}

\subsection{FE parametric analyses}

3.2.1 Influence of web depth-to-thickness ratio and span-to-depth ratio of joist

It is widely known that the bending capacities of CFS members are affected by the web depth-to-thickness ratio and span-to-depth ratio of the joists $[12,13]$. Consequently, the ultimate load is also influenced by these two factors. In this study, three alternative spans, namely 3,048, 4,064, and 5,080 $\mathrm{mm}$, and five different web thicknesses, i.e., $2.55,1.7,1.27,1.02$, and $0.85 \mathrm{~mm}$, were investigated. The details of the modeled specimens and results are presented in Table 6, where $l$ is the span of the joist, and $t$ is the thickness of josits. The comparisons are illustrated in Fig. 9, where C254-12-100 implies that the web depth of the joist $h$ is $254 \mathrm{~mm}$, span-to-depth ratio of the joist $l / h$ is 12 , and web depth-to-thickness ratio of the joist $h / t$ is 100 . As shown in Fig. 9, the variation in the web depth-to-thickness ratio substantially affected the ultimate load. The ultimate bending capacity reduced significantly as the web depth-to-thickness ratio increased. For specimens with a span-to-depth ratio of 12 , when the web depth-to-thickness ratio increased from 100 to 150,150 to 200, 200 to 250 , and 250 to 300 , the corresponding reductions in the ultimate capacity of the composite floor were $34.40,37.46,36.20$, and $31.41 \%$, respectively. Therefore, the ultimate capacity of the composite floor was influenced most significantly by the web depth-to-thickness ratio. Moreover, with increasing web depth-to-thickness ratio, the effect of the span-to-depth ratio was small and negligible. For example, when the web depth-to-thickness ratio was 100 , the ultimate capacity of the specimen with a span-to-depth ratio of 12 was $31.7 \%$ higher than that of the specimen with a span-to-depth ratio of 16. However, when the web depth-to-thickness ratio was 300 , the ultimate capacity only increased by $14.9 \%$. This is because when the web depth-tothickness ratio was 300 , the web thickness of the joist was only $0.85 \mathrm{~mm}$; therefore, failure of the floors occurred due to the lower buckling load of the CFS members. Thus, the span-to-depth ratio had little influence on the failure mechanism.

Table 6

Influence of web depth-to-thickness ratio and span-to-depth ratio of joist on the capacity of composite floor

\begin{tabular}{cccc}
\hline Specimen & $l(\mathrm{~mm})$ & $t(\mathrm{~mm})$ & $P^{*}{ }_{\mathrm{u}}(\mathrm{kN})$ \\
\hline C254-12-100 & 3048 & 2.55 & 244.276 \\
C254-12-150 & 3048 & 1.7 & 160.247 \\
C254-12-200 & 3048 & 1.27 & 100.225 \\
C254-12-250 & 3048 & 1.02 & 63.939 \\
C254-12-300 & 3048 & 0.85 & 43.853 \\
C254-16-100 & 4064 & 2.55 & 185.525 \\
C254-16-150 & 4064 & 1.7 & 126.963 \\
C254-16-200 & 4064 & 1.27 & 89.441 \\
C254-16-250 & 4064 & 1.02 & 59.870 \\
C254-16-300 & 4064 & 0.85 & 38.167 \\
C254-20-100 & 5080 & 2.55 & 174.142 \\
C254-20-150 & 5080 & 1.7 & 117.796 \\
C254-20-200 & 5080 & 1.27 & 81.629 \\
C254-20-250 & 5080 & 1.02 & 58.718 \\
C254-20-300 & 5080 & 0.85 & 37.293 \\
\hline
\end{tabular}

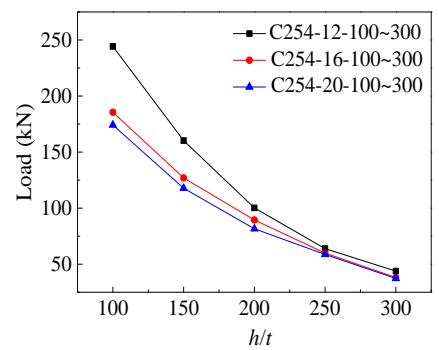

Fig. 9 Effect of web depth-to-thickness ratio on floors with different span-to-depth ratios

Fig. 10 illustrates the load-deflection curves for different span-to-depth ratios and web depth-to-thickness ratios. The ultimate deflection and initial slope of the load-deflection curves in Fig. 10(a) demonstrate that the bending stiffness and ductility of floors also reduced with increasing web depth-tothickness ratio when the span-to-depth ratio was 12 . This is attributable to the increase in the CFS joist thickness; a constant web depth of the joists can increase the section modulus and consequently increase the bending stiffness of the composite floor. However, as depicted in Fig. 9 and Fig. 10(b), the ultimate load and bending stiffness were not improved when the span-to-depth ratio was reduced from 20 to 16 .

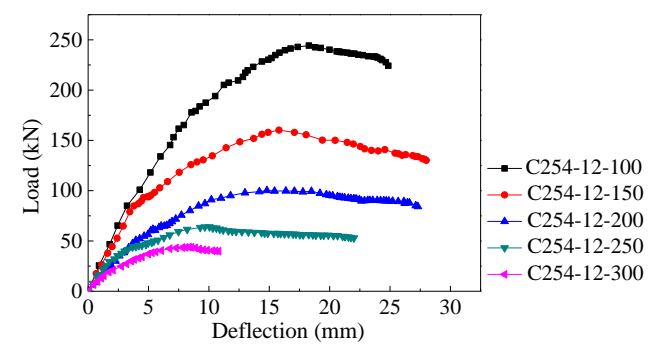

(a) Varying web depth-to-thickness ratio $(l / h=12)$

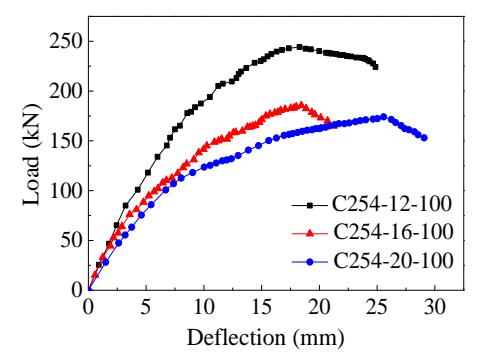

(b) Varying span-to-depth ratio $(h / t=100)$

Fig. 10 Comparison of load-deflection curves for floors with different span-to-depth ratios and web depth-to-thickness ratios

\subsubsection{Influence of screw spacing}

As the test results indicated that the screw connections between the CFS joist and CFS form-deck were extremely important for the composite action of the floors, a parametric research was performed to obtain the influence of screw spacing on both the ultimate load and bending stiffness of CFS-concrete floors. Three values for spacing along the perimeter, i.e., 252, 126, and $63 \mathrm{~mm}$, were considered when the spacing in the field was $252 \mathrm{~mm}$. On the other hand, when the spacing along the perimeter was $126 \mathrm{~mm}$, three values of spacing in the field, i.e., 315,252 , and $126 \mathrm{~mm}$, were evaluated.

From the results presented in Table 7 and the load-deflection curves in Fig. 11, where C254-s63/252 indicates a joist height of $254 \mathrm{~mm}$, screw spacing along the perimeter of $63 \mathrm{~mm}$, and screw spacing in the field of $252 \mathrm{~mm}$, it can be concluded that decreasing the screw spacing along the perimeter from 252 $\mathrm{mm}$ to $126 \mathrm{~mm}$ and subsequently from $126 \mathrm{~mm}$ to $63 \mathrm{~mm}$ resulted in a gradual increase in ultimate load, with enhancements in capacity of up to $3.0 \%$ and $4.3 \%$, respectively. However, the initial bending stiffness exhibited no difference when only the screw spacing along the perimeter was varied. As shown in Fig. 11(b), reducing the screw spacing in the field from $315 \mathrm{~mm}$ to $252 \mathrm{~mm}$ and subsequently from $252 \mathrm{~mm}$ to $126 \mathrm{~mm}$ increased the ultimate load by up to $8.4 \%$ and $3.9 \%$, respectively. When the screw spacing in the 
field was $315 \mathrm{~mm}$, the larger screw spacing resulted in a reduced number of screws between the CFS joists and the CFS form-deck, subsequently causing a sharp decline in the ultimate capacity of the floor. As presented in Table 7, only a little variation was observed for the capacities of composite floors with other values of screw spacing. Therefore, considering the load and construction simplicity, the screw spacing of s126/252 used in the test was deemed to be reasonable.

Table 7

Influence of screw spacing on the capacity of composite floor

\begin{tabular}{cccc}
\hline \multirow{2}{*}{ Specimen } & \multicolumn{2}{c}{ Screw spacing $(\mathrm{mm})$} & \multirow{2}{*}{$P^{*}{ }_{\mathrm{u}}(\mathrm{kN})$} \\
\cline { 2 - 3 } & Perimeter & In the field & \\
\hline C254-s252/252 & 252 & 252 & 116.324 \\
C254-s126/252 & 126 & 252 & 119.794 \\
C254-s63/252 & 63 & 252 & 124.945 \\
C254-s126/126 & 126 & 126 & 124.142 \\
C254-s126/315 & 126 & 315 & 110.499 \\
\hline
\end{tabular}

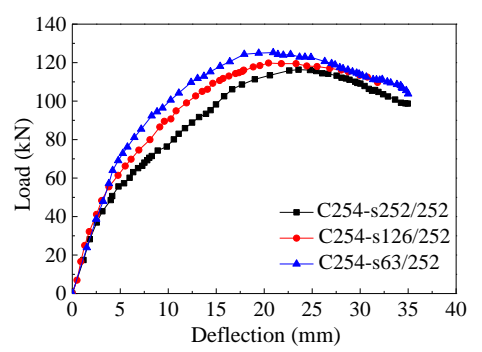

(a) Varying spacing along perimeter

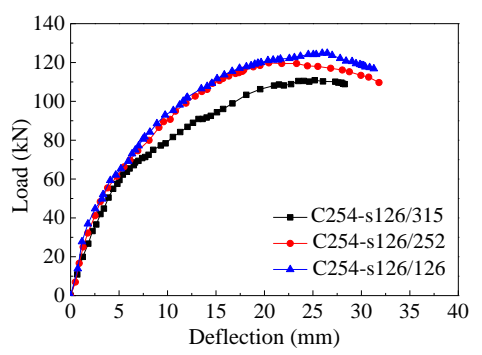

(b) Varying spacing in the field

Fig. 11 Comparison of load-deflection curves for floors with different values of screw spacing

\subsubsection{Influence of concrete slab thickness}

Owing to the large cracks on the concrete slab that occurred during the tests and the conclusion in [14] that a thicker slab may increase the bending resistance of a composite beam, five slab thicknesses in Table 8 are considered to better understand the influence of concrete slab thickness on the ultimate capacity of CFS-concrete composite floors. The concrete slab thickness is the distance from the valley of the shallow CFS form deck to the top surface of the concrete slab. The concrete properties adopted in the FE model were acquired from the results of the material tests discussed in subsection 2.2. As indicated in Table 8 , the ultimate load increased with increasing slab thickness. For example, when the slab thickness was increased by $10 \mathrm{~mm}$ from $30 \mathrm{~mm}$, the ultimate bearing capacities of the composite floors were increased by $23.40 \%$, $6.50 \%, 0.33 \%$, and $4.33 \%$, respectively. As shown, enhancement in the ultimate load was apparent when the slab thickness increased from $30 \mathrm{~mm}$ to $40 \mathrm{~mm}$, whereas varying the slab thickness from $40 \mathrm{~mm}$ to $70 \mathrm{~mm}$ exhibited a small impact. Fig. 12 shows the load-deflection curves of the specimens. Before the loading reached $60 \mathrm{kN}$, the slopes of all curves were similar, indicating that the influence of slab thickness on the initial stiffness of the floors was negligible. However, after $60 \mathrm{kN}$, the specimen with the slab thickness of $30 \mathrm{~mm}$ showed the most severe stiffness degradation. Therefore, the minimum concrete slab thickness is suggested to be $40 \mathrm{~mm}$.
Table 8

Influence of concrete slab thickness on the capacity of composite floor

\begin{tabular}{ccc}
\hline Specimen & Slab thickness $(\mathrm{mm})$ & $P^{*}{ }_{\mathrm{u}}(\mathrm{kN})$ \\
\hline $\mathrm{C} 254-\mathrm{o} 30$ & 30 & 97.080 \\
$\mathrm{C} 254-\mathrm{o} 40$ & 40 & 119.794 \\
$\mathrm{C} 254-050$ & 50 & 127.585 \\
$\mathrm{C} 254-\mathrm{o} 60$ & 60 & 128.007 \\
$\mathrm{C} 254-\mathrm{o} 70$ & 70 & 133.546 \\
\hline
\end{tabular}

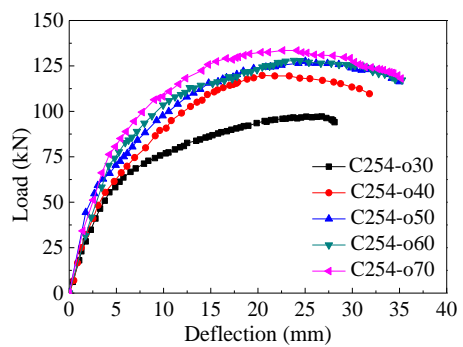

Fig. 12 Comparison of load-deflection curves for floors with different concrete slab thickness

\subsubsection{Influence of steel strength of the joist}

Specimens C254-Q235 and C254-Q318 were identical in all aspects but had different values of steel strength for their joists. The steel yield strength of C254-Q235 was $235 \mathrm{MPa}$, whereas that of $\mathrm{C} 254-\mathrm{Q} 318$ was $318 \mathrm{MPa}$. As presented in Table 9, increasing the steel yield strength resulted in an increase in the ultimate load, with enhancements in capacity of up to $18.1 \%$. This is primarily due to the increase in the steel yield strength, which resulted in an increased bending section modulus of the CFS, thereby increasing the ultimate load of the composite floors. Additionally, the specimen with a higher steel yield strength of the joists achieved a higher initial stiffness, as shown in Fig. 13.

Table 9

Influence of steel strength of joists on the capacity of composite floor

\begin{tabular}{ccc}
\hline Specimen & Steel yield strength $(\mathrm{MPa})$ & $P^{*}{ }_{\mathrm{u}}(\mathrm{kN})$ \\
\hline $\mathrm{C} 254-\mathrm{Q} 235$ & 235 & 101.38 \\
$\mathrm{C} 254-\mathrm{Q} 318$ & 318 & 119.79 \\
\hline
\end{tabular}

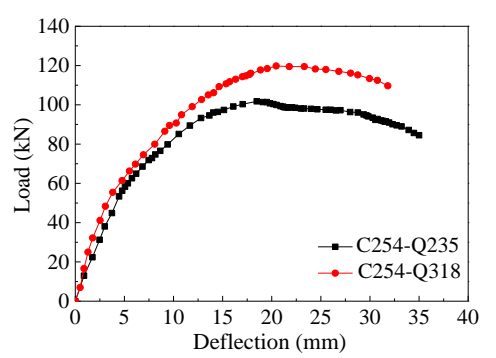

Fig. 13 Comparison of load-deflection curves for floors with different values of steel strength for joists

Hence, according to the above analyses, it can be concluded that the web depth-to-thickness ratio, span-to-depth ratio of the joists, and steel strength had significant influences on the ultimate capacity of the composite floor. Therefore, only these three factors were considered in the method for evaluating the bending capacity of composite floors in section 4 . 


\section{Simplified method for calculating the ultimate moment capacity of CFS-concrete floors}

A simplified method, the core of which comprises the segregation of the composite floor model and the determination of the corresponding comprehensive corrected coefficient of each component, has been developed for calculating the ultimate moment capacity of the CFS-concrete composite floor system.

\subsection{Simplified calculation model}

As reported in [15], the enhancement in ultimate moment capacity of composite floors is linearly proportional to the number of joists. Therefore, the CFS-concrete composite floor was simplified to a configuration of one Tshape composite beam and two inverted L-shape composite beams (hereinafter L-shape composite beam), as illustrated in Fig. 14. Hence, the ultimate moment capacity of the floor can be obtained from the summation of the ultimate moment capacity of the T- and L-shape beams. This subsection aims to validate this simplified method through an FE analysis.

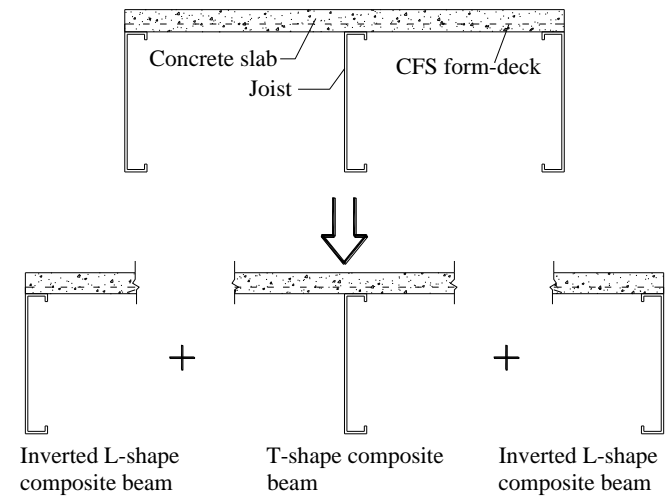

Fig.14 Equivalent diagram of composite floor

The FE models of the simplified T- and L-shape composite beams were developed by using the method detailed in subsection 3.1. The assumptions are as follows: 1. The floor slab at each cross section exhibits the same displacement in the $y$ direction, e.g., points $a, b$, and $c$ shown in Fig. 15(a) show the same deflection ( $U_{\text {ay }}=U_{\text {by }}=U_{\text {cy }}$ ). 2. The composite floor has no deflection along the $x$ direction, and the boundary conditions of the T-shape composite beam are as shown in Fig. 15(b).

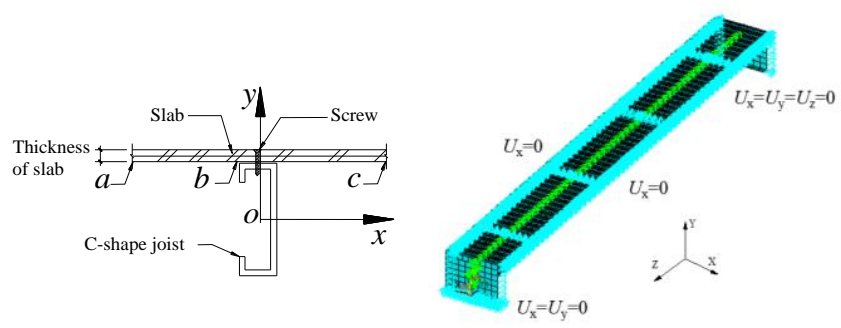

(a) Simplified T-shape model

(b) Boundary conditions

Fig. 15 Simplified FE model of T-shape composite beam

The simplified FE model for the T-shape composite beam is shown in Fig. 15(b). Because no shear lag effects were observed in the tests, the slab width was modeled as equal to the joist spacing (i.e., $400 \mathrm{~mm}$ ) [16]. Furthermore, overall models with different numbers of joists were developed, and comparisons of the ultimate moment capacities between the overall and simplified models are presented in Table 10. In Table 10, $M_{\mathrm{u}}$ is the ultimate moment capacity of the overall model, $M_{\mathrm{u}-\mathrm{T}}$ is the ultimate moment capacity of a single T-shape model, $M_{\mathrm{u}-\mathrm{L}}$ is the ultimate moment capacity of a single inverted L-shape model, $M_{\mathrm{u}-\mathrm{S}}$ is the ultimate moment capacity from simplified method and $M_{\mathrm{u}-\mathrm{F}}$ is the ultimate moment capacity from FE analysis.
Table 10

Comparisons of ultimate moment capacities between overall model and simplified model

\begin{tabular}{|c|c|c|c|c|c|c|c|}
\hline$l \times b(\mathrm{~mm})$ & $\begin{array}{l}\text { T-shape } \\
\text { beam } n_{1}\end{array}$ & $\begin{array}{l}\text { Inverted } \\
\text { L-shape } \\
\text { beam } n_{2}\end{array}$ & $\begin{array}{c}M_{\mathrm{u}-\mathrm{T}} \\
(\mathrm{kN} \cdot \mathrm{m})\end{array}$ & $\begin{array}{c}M_{\mathrm{u}-\mathrm{L}} \\
(\mathrm{kN} \cdot \mathrm{m})\end{array}$ & $\begin{array}{c}M_{\mathrm{u}-\mathrm{S}} \\
(\mathrm{kN} \cdot \mathrm{m})\end{array}$ & $\begin{array}{c}M_{\mathrm{u}-\mathrm{F}} \\
(\mathrm{kN} \cdot \mathrm{m})\end{array}$ & $\begin{array}{c}M_{\mathrm{u}-\mathrm{S}} / \\
M_{\mathrm{u}-\mathrm{F}}\end{array}$ \\
\hline $3600 \times 800$ & 1 & 2 & \multirow{4}{*}{19.52} & \multirow{4}{*}{18.20} & 55.92 & 53.93 & 1.037 \\
\hline $3600 \times 1200$ & 2 & 2 & & & 75.43 & 77.32 & 0.976 \\
\hline $3600 \times 1600$ & 3 & 2 & & & 94.95 & 97.87 & 0.970 \\
\hline $3600 \times 2000$ & 4 & 2 & & & 114.46 & 117.58 & 0.974 \\
\hline
\end{tabular}

As indicated, the difference between the overall and simplified models is within $4 \%$, thereby demonstrating the validity of this method in simplifying the composite floor to T-shape and inverted L-shape composite beams. Thus, the ultimate moment capacity of the CFS-concrete composite floor can be considered as the summation of the individual capacities of the T- and L-shape composite beams, which can be defined as Eq. (1).

$M_{\mathrm{u}}=n_{1} M_{\mathrm{u}-\mathrm{T}}+n_{2} M_{\mathrm{u}-\mathrm{L}}$

where $M_{\mathrm{u}-\mathrm{T}}$ and $M_{\mathrm{u}-\mathrm{L}}$ are the ultimate moment capacities of the T- and L-shape composite beams, respectively; $n_{1}$ and $n_{2}$ are the number of T- and L-shape composite beams, respectively.

Moreover, a comprehensive corrected coefficient $\eta$ was introduced to consider the effects of key factors, such as the web depth-to-thickness ratio, span-to-depth ratio of the joists, and steel strength. Therefore, the ultimate bending capacity of the T- and L-shape CFS-concrete composite beams can be calculated through Eqs. (2) and (3).

$M_{\mathrm{u}-\mathrm{TL})}=\eta_{\mathrm{TL}(\mathrm{L})} M_{\mathrm{y}-\mathrm{TL})}$

where $\eta_{\mathrm{T}}$ and $\eta_{\mathrm{L}}$ are the comprehensive corrected coefficients of the T- and Lshape composite beams, respectively; $M_{\mathrm{y}-\mathrm{T}}$ and $M_{\mathrm{y}-\mathrm{L}}$ are the elastic bending moment capacities of the T- and L-shape composite beams, respectively, which can be calculated using Eq. (3).

$M_{\mathrm{y}-\mathrm{TL})}=W_{\mathrm{T}(\mathrm{L})} f_{\mathrm{y}}$

where $W_{\mathrm{T}(\mathrm{L})}$ is the bending modulus of the T- or L-shape composite beam [17], and $f_{\mathrm{y}}$ is the steel yield strength.

\subsection{Evaluation of comprehensive corrected coefficient $\eta$}

The comprehensive corrected coefficient $\eta$ is affected by the web depthto-thickness ratio, span-to-depth ratio of the joists, and steel strength. The influences of these parameters were investigated by extensive FE analyses on a selected T-shape composite beam. An FE model of the L-shape composite beam was also developed to examine the coefficient $\eta_{\mathrm{L}}$. The method for all FE models was the same as that used in subsection 3.1, and only the yield strength of the steel joists was changed to $235 \mathrm{MPa}$ or $345 \mathrm{MPa}$.

The values of the comprehensive corrected coefficient of the composite beam in which the yield strength of the steel joists was $235 \mathrm{MPa}$ are presented in Table 11. On the other hand, Table 12 lists the values of the comprehensive corrected coefficients of the composite beam in which the yield strength of the steel joists was $345 \mathrm{MPa}$. The results presented in Tables 11 and 12 were obtained using two different steel strengths, namely $235 \mathrm{MPa}$ and $345 \mathrm{MPa}$, respectively, and three web depths, i.e., 205, 254, and $305 \mathrm{~mm}$. For each web depth, three span-to-depth ratios, namely 12,16 , and 20 , and four web depthto-thickness ratios, i.e., $100,150,200$, and 250 were employed. $M_{\mathrm{u}-\mathrm{T}}$ and $M_{\mathrm{y}-\mathrm{T}}$ are the ultimate moment capacity and elastic bending moment capacity of the T-shape composite beam, respectively, whereas $M_{\mathrm{u}-\mathrm{L}}$ and $M_{\mathrm{y}-\mathrm{L}}$ are those of the inverted L-shape composite beam, respectively. Furthermore, $\eta_{\mathrm{T}-235}$ and $\eta_{\mathrm{L}-235}$ are the comprehensive corrected coefficients of the $\mathrm{T}$ and $\mathrm{L}$-shape composite beams, respectively, in which the yield strength of the steel joists was $235 \mathrm{MPa}$; meanwhile, $\eta_{\mathrm{T}-345}$ and $\eta_{\mathrm{L}-345}$ represent those with a yield strength of $345 \mathrm{MPa}$, respectively.

As mentioned in Eq. (2),

$\eta_{\mathrm{T}-235}=\frac{M_{\mathrm{u}-\mathrm{T}}}{M_{\mathrm{y}-\mathrm{T}}}$

and this is similar for $\eta_{\mathrm{L}-235}, \eta_{\mathrm{T}-345}$ and $\eta_{\mathrm{L}-345}$. 
Table 11

$\eta$ of the composite beam with $235 \mathrm{MPa}$ yield strength of steel joist

\begin{tabular}{|c|c|c|c|c|c|c|c|c|c|c|}
\hline \multicolumn{5}{|c|}{ Details of steel joist (mm) } & \multicolumn{2}{|c|}{$\mathrm{FE}$ analysis $M_{\mathrm{u}}(\mathrm{kN} \cdot \mathrm{m})$} & \multicolumn{2}{|c|}{ Elastic theory $M_{\mathrm{y}}(\mathrm{kN} \cdot \mathrm{m})$} & \multirow{2}{*}{$\eta_{\mathrm{T}-235}$} & \multirow{2}{*}{$\eta_{\mathrm{L}-235}$} \\
\hline Dimension of joist & $l / h$ & $h / t$ & $l$ & $t$ & $M_{\mathrm{u}-\mathrm{T}}$ & $M_{\mathrm{u}-\mathrm{L}}$ & $M_{\mathrm{y}-\mathrm{T}}$ & $M_{\mathrm{y}-\mathrm{L}}$ & & \\
\hline \multirow{12}{*}{$\mathrm{C} 205 \times 41 \times 14 \times \mathrm{t}$} & \multirow{4}{*}{12} & 100 & 2460 & 2.05 & 16.821 & 14.634 & 13.710 & 12.966 & 1.227 & 1.129 \\
\hline & & 150 & 2460 & 1.37 & 10.756 & 9.633 & 9.380 & 8.974 & 1.147 & 1.073 \\
\hline & & 200 & 2460 & 1.02 & 7.475 & 7.109 & 7.085 & 6.824 & 1.055 & 1.042 \\
\hline & & 250 & 2460 & 0.82 & 5.710 & 5.529 & 5.751 & 5.559 & 0.993 & 0.994 \\
\hline & \multirow{4}{*}{16} & 100 & 3280 & 2.05 & 17.523 & 16.631 & 13.710 & 12.966 & 1.278 & 1.283 \\
\hline & & 150 & 3280 & 1.37 & 10.820 & 10.876 & 9.380 & 8.974 & 1.153 & 1.212 \\
\hline & & 200 & 3280 & 1.02 & 7.109 & 8.062 & 7.085 & 6.824 & 1.003 & 1.181 \\
\hline & & 250 & 3280 & 0.82 & 5.568 & 6.037 & 5.751 & 5.559 & 0.968 & 1.086 \\
\hline & \multirow{4}{*}{20} & 100 & 4100 & 2.05 & 16.902 & 15.390 & 13.710 & 12.966 & 1.233 & 1.187 \\
\hline & & 150 & 4100 & 1.37 & 11.377 & 10.814 & 9.380 & 8.974 & 1.213 & 1.205 \\
\hline & & 200 & 4100 & 1.02 & 8.365 & 8.062 & 7.085 & 6.824 & 1.181 & 1.181 \\
\hline & & 250 & 4100 & 0.82 & 6.609 & 6.037 & 5.751 & 5.559 & 1.149 & 1.086 \\
\hline \multirow{12}{*}{$\mathrm{C} 254 \times 41 \times 14 \times \mathrm{t}$} & \multirow{4}{*}{12} & 100 & 3060 & 2.55 & 27.415 & 23.443 & 22.539 & 21.060 & 1.216 & 1.113 \\
\hline & & 150 & 3060 & 1.7 & 17.190 & 15.417 & 15.469 & 14.650 & 1.111 & 1.052 \\
\hline & & 200 & 3060 & 1.27 & 12.102 & 11.442 & 11.752 & 11.229 & 1.030 & 1.019 \\
\hline & & 250 & 3060 & 1.02 & 9.142 & 9.096 & 9.541 & 9.169 & 0.958 & 0.992 \\
\hline & \multirow{4}{*}{16} & 100 & 4080 & 2.55 & 27.249 & 25.171 & 22.539 & 21.060 & 1.209 & 1.195 \\
\hline & & 150 & 4080 & 1.7 & 16.422 & 16.198 & 15.469 & 14.650 & 1.062 & 1.106 \\
\hline & & 200 & 4080 & 1.27 & 11.664 & 11.545 & 11.752 & 11.229 & 0.992 & 1.028 \\
\hline & & 250 & 4080 & 1.02 & 9.374 & 8.741 & 9.541 & 9.169 & 0.982 & 0.953 \\
\hline & \multirow{4}{*}{20} & 100 & 5100 & 2.55 & 27.649 & 26.826 & 22.539 & 21.060 & 1.227 & 1.274 \\
\hline & & 150 & 5100 & 1.7 & 18.602 & 17.616 & 15.469 & 14.650 & 1.203 & 1.202 \\
\hline & & 200 & 5100 & 1.27 & 13.752 & 12.495 & 11.752 & 11.229 & 1.170 & 1.113 \\
\hline & & 250 & 5100 & 1.02 & 10.838 & 9.818 & 9.541 & 9.169 & 1.136 & 1.071 \\
\hline \multirow{12}{*}{$\mathrm{C} 305 \times 41 \times 14 \times \mathrm{t}$} & \multirow{4}{*}{12} & 100 & 3660 & 3.05 & 39.766 & 33.448 & 34.458 & 31.850 & 1.154 & 1.050 \\
\hline & & 150 & 3660 & 2.0 & 24.234 & 22.555 & 23.436 & 21.968 & 1.034 & 1.027 \\
\hline & & 200 & 3660 & 1.5 & 17.801 & 17.129 & 17.932 & 16.974 & 0.993 & 1.009 \\
\hline & & 250 & 3660 & 1.22 & 13.874 & 13.876 & 14.765 & 14.067 & 0.940 & 0.986 \\
\hline & \multirow{4}{*}{16} & 100 & 4880 & 3.05 & 38.900 & 37.777 & 34.458 & 31.850 & 1.129 & 1.186 \\
\hline & & 150 & 4880 & 2.0 & 24.809 & 23.601 & 23.436 & 21.968 & 1.059 & 1.074 \\
\hline & & 200 & 4880 & 1.5 & 17.934 & 17.361 & 17.932 & 16.974 & 1.000 & 1.023 \\
\hline & & 250 & 4880 & 1.22 & 14.353 & 13.249 & 14.765 & 14.067 & 0.972 & 0.942 \\
\hline & \multirow{4}{*}{20} & 100 & 6100 & 3.05 & 41.289 & 40.122 & 34.458 & 31.850 & 1.198 & 1.260 \\
\hline & & 150 & 6100 & 2.0 & 27.420 & 25.429 & 23.436 & 21.968 & 1.170 & 1.158 \\
\hline & & 200 & 6100 & 1.5 & 20.000 & 18.376 & 17.932 & 16.974 & 1.115 & 1.083 \\
\hline & & 250 & 6100 & 1.22 & 15.578 & 14.754 & 14.765 & 14.067 & 1.055 & 1.049 \\
\hline
\end{tabular}


Table 12

$\eta$ of the composite beam with $345 \mathrm{MPa}$ yield strength of steel joist

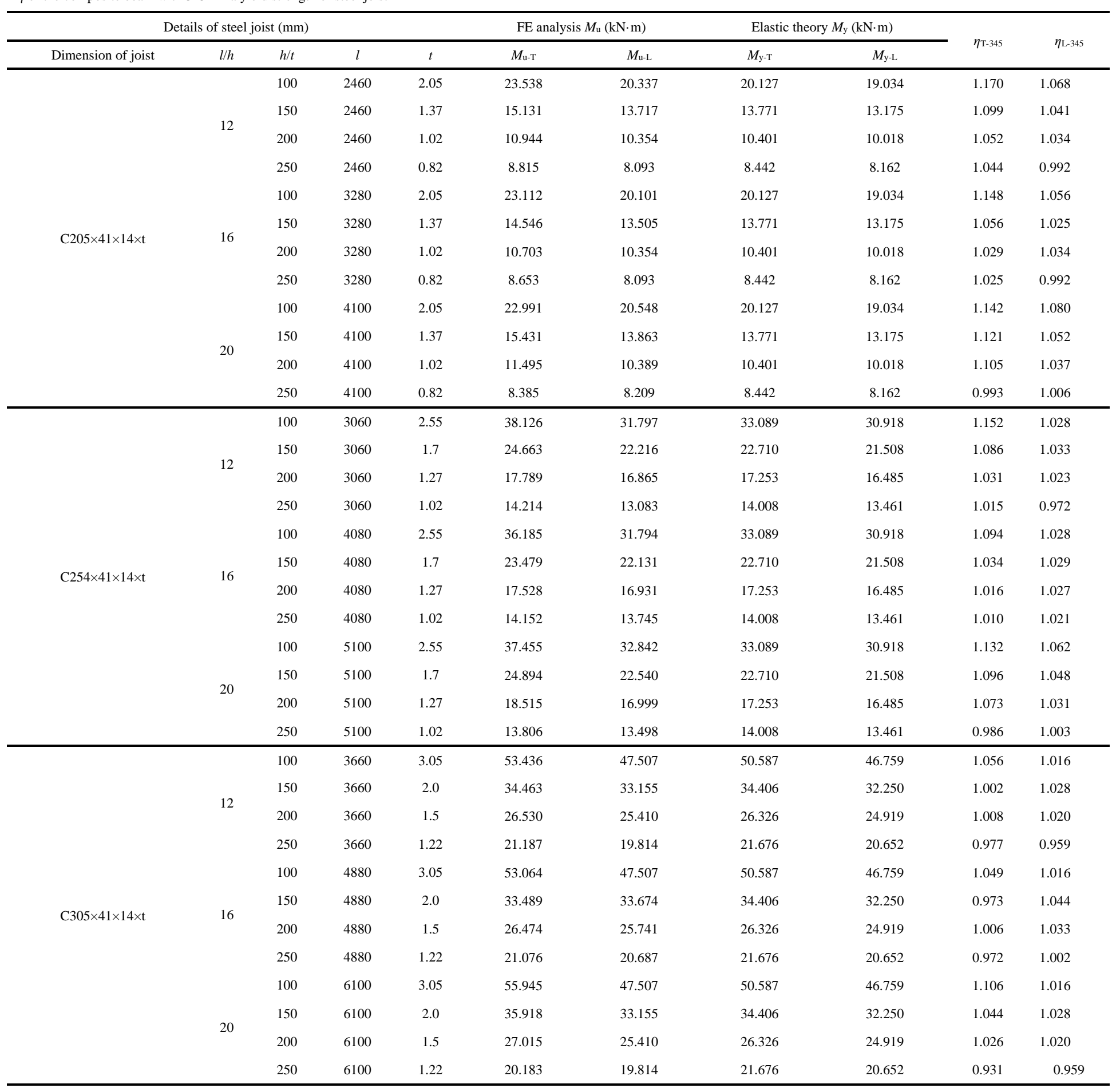

For a more quantitative analysis, a regression analysis of the data from Tables 11 and 12 was conducted using the MATLAB® (The Mathworks Inc., USA) function "Isqcurvefit" to identify the relationship between the comprehensive corrected coefficient and independent variables such as web depth-to-thickness ratio, span-to-depth ratio of the joists, and steel strength. The equations are expressed as

$\eta_{\mathrm{T}-235}=1.613-0.0295 \sqrt{l / h}-0.0287 \sqrt{h / t}$

$\eta_{\mathrm{T}-345}=1.779-0.069 \sqrt{l / h}-0.0391 \sqrt{h / t}$
$\eta_{\mathrm{L}-235}=1.5753-0.0255 \sqrt{l / h}-0.0312 \sqrt{h / t}$

$\eta_{\mathrm{L}-345}=1.3755-0.029 \sqrt{l / h}-0.0333 \sqrt{h / t}$

\subsection{Result validation of the proposed method}

According to Eqs. (1) and (2), the ultimate moment capacity of the CFSconcrete composite floor, in which the yield strengths of the steel joists are 235 MPa and $345 \mathrm{MPa}$, respectively, can be calculated by Eqs. (9) and (10).

$M_{\mathrm{u}}=n_{1} \eta_{\mathrm{T}-235} M_{\mathrm{y}-\mathrm{T}}+n_{2} \eta_{\mathrm{L}-235} M_{\mathrm{y}-\mathrm{L}}$ 
$M_{\mathrm{u}}=n_{1} \eta_{\mathrm{T}-345} M_{\mathrm{y}-\mathrm{T}}+n_{2} \eta_{\mathrm{L}-345} M_{\mathrm{y}-\mathrm{L}}$

In Eqs. (9) and (10), $M_{\mathrm{y}-\mathrm{T}}$ and $M_{\mathrm{y}-\mathrm{L}}$ can be obtained according to Eq. (3), whereas $\eta_{\mathrm{T}}$ and $\eta_{\mathrm{L}}$ can be calculated according to Eqs. (5) to (8). Additionally, a linear interpolation method can be adopted for other yield strengths. The proposed method can provide a simple calculation and design approach for designers to estimate the ultimate moment capacity of CFS-concrete composite floor systems.

For validating the proposed method, the elastic bending moment capacity of the composite beam was calculated according to Eq. (3). Values of the ultimate moment capacity obtained from the simplified method and FE analysis are listed and compared in Table 13. The calculated ultimate moment capacities based on Eqs. (9) to (10) were compared with those of specimens BM-1 and BM-2 in the test and FE analysis. The results are presented in Table 14 , in which $M_{\mathrm{u}-\mathrm{E}}, M_{\mathrm{u}-\mathrm{F}}$, and $M_{\mathrm{u}-\mathrm{S}}$ represent the ultimate moment capacity obtained from the test, FE analysis, and simplified method, respectively. The errors were all less than $9 \%$, indicating that the results calculated by the suggested method agreed well with those obtained from the FE analysis. As indicated in Table 14, strong agreements were achieved among the ultimate moment capacities of both floors obtained from the proposed method, and the experimental and numerical investigations. According to the FE parametric analyses results of section 3.2, the influences of both screw spacing and concrete slab thickness were insignificant and not considered in the evaluation of the comprehensive corrected coefficient. However, if the effects of both screw spacing and concrete slab thickness were considerable, the comprehensive corrected coefficient should be investigated further. Therefore, the proposed method only applies to the CFS-concrete composite floor in which the screw spacing and concrete slab thickness have small effects on the ultimate moment capacity of CFS-concrete floors.

Table 13

Comparison of the ultimate moment capacity from simplified method and FE analysis

\begin{tabular}{cccccccc}
\hline$l \times b(\mathrm{~mm})$ & $n_{1}$ & $n_{2}$ & $\begin{array}{c}\eta_{\mathrm{T}} M_{\mathrm{y}-\mathrm{T}} \\
(\mathrm{kN} \cdot \mathrm{m})\end{array}$ & $\begin{array}{c}\eta_{\mathrm{L}} M_{\mathrm{y}-\mathrm{L}} \\
(\mathrm{kN} \cdot \mathrm{m})\end{array}$ & $\begin{array}{c}M_{\mathrm{u}-\mathrm{S}} \\
(\mathrm{kN} \cdot \mathrm{m})\end{array}$ & $\begin{array}{c}M_{\mathrm{u}-\mathrm{F}} \\
(\mathrm{kN} \cdot \mathrm{m})\end{array}$ & $\begin{array}{c}M_{\mathrm{uS}} \\
/ M_{\mathrm{u}-\mathrm{F}}\end{array}$ \\
\hline $3600 \times 800$ & 1 & 2 & & & 56.42 & 53.928 & 1.046 \\
$3600 \times 1200$ & 2 & 2 & & & 75.6 & 77.32 & 0.978 \\
$3600 \times 1600$ & 3 & 2 & 19.18 & 18.62 & 94.78 & 97.87 & 0.968 \\
$3600 \times 2000$ & 4 & 2 & & & 113.96 & 117.58 & 0.969 \\
\hline
\end{tabular}

Table 14

Comparison of the ultimate moment capacity from simplified method and FE analysis

\begin{tabular}{|c|c|c|c|c|c|c|c|c|c|}
\hline Specimen & $n_{1}$ & $n_{2}$ & $\eta_{\mathrm{T}} M_{\mathrm{y}-\mathrm{T}}(\mathrm{kN} \cdot \mathrm{m})$ & $\eta_{\mathrm{L}} M_{\mathrm{y}-\mathrm{L}}(\mathrm{kN} \cdot \mathrm{m})$ & $M_{\mathrm{u}-\mathrm{S}}(\mathrm{kN} \cdot \mathrm{m})$ & $M_{\mathrm{u}-\mathrm{E}}(\mathrm{kN} \cdot \mathrm{m})$ & $M_{\mathrm{u}-\mathrm{F}}(\mathrm{kN} \cdot \mathrm{m})$ & $M_{\mathrm{u}-\mathrm{S}} / M_{\mathrm{u}-\mathrm{E}}$ & $M_{\mathrm{u}-\mathrm{S}} / M_{\mathrm{u}-\mathrm{F}}$ \\
\hline BM-1 & 1 & 2 & 19.18 & 18.62 & 56.42 & 50.88 & 52.11 & 1.11 & 1.08 \\
\hline
\end{tabular}

\section{Conclusion}

In this study, two composite CFS specimens were examined by full-scale bending tests to investigate the influence of slab materials on the bending performance of CFS-concrete composite floors at first. Subsequently, FE models of the tested floor were established, and the model was validated using the test results. Good agreements between the experimental and numerical results were achieved and the established FE model was subsequently adopted for parametric analyses. The influences of different parameters, such as web depth-to-thickness ratio, span-to-depth ratio of the joist, screw spacing, concrete slab thickness, and steel strength, on the ultimate load were investigated with various floor configurations. Consequently, based on the equivalent model of composite floors and the proposed equations for evaluating the comprehensive corrected coefficient for the simplified beam models, a simplified method for evaluating the ultimate moment capacity of CFS-concrete floors was proposed. The results obtained from the proposed method showed good agreements with those of both experimental and numerical investigations. The conclusions from the investigation are as follows

(1) Varying the slab material had no significant effect on the ultimate load, but a higher stiffness was observed when the slab material was changed from GSU to FAC.

(2) The web depth-to-thickness ratio, span-to-depth ratio, and steel strength of the joists affected the ultimate load significantly and consequently the bending capacity of the floors. A higher web depth-to-thickness ratio resulted in a smaller ultimate bending capacity of the CFS-concrete floor. Meanwhile, a smaller span-to-depth ratio led to a higher ultimate bending capacity. Increasing the steel strength of the joists correspondingly increased the ultimate capacity of the CFS composite floors.

(3) Increasing the screw spacing and concrete slab thickness had little influence on the ultimate load; therefore, they were not taken into consideration in the proposed equations for calculating the ultimate moment capacity.

The composite action between the CFS joists and GSU subfloors, which is neglected in the current design standard owing to the difficulty in quantifying the influence of the composite action on the bending capacity of the floors, was considered in the simplified method. Finally, the proposed method was validated using the results of the experimental and numerical investigations, and therefore, can be applied in engineering practice.

\section{Acknowledgments}

The authors wish to acknowledge the support of the Natural Science Foundation of China (Grant No.: 51678060) and Fundamental Research Funds for the Central Universities (Grant No.:310828171011). Any opinions, findings, and conclusions or recommendations expressed herein are those of the authors and do not necessarily reflect the views of the sponsors.

\section{References}

[1] Steel Framing Alliance. Poly Canyon Village student housing. Steel Success Stories, 2010

[2] Hanaor A., "Tests of composite beams with cold-formed sections", Journal of Construction Steel Research, 54(2), 245-264, 2000.

[3] Lakkavalli B.S. and Liu Y., "Experimental study of composite cold-formed steel Csection floor joists", Journal of Construction Steel Research, 62(10), 995-1006, 2006.

[4] Irwan J.M., Hanizah A.H. and Azmi I., "Test of shear transfer enhancement in symmetric cold-formed steel-concrete composite beams", Journal of Construction Steel Research, 65(12), 2087-2098, 2016.

[5] Irwan J.M., Hanizah A.H., Azmib I. and Koh H.B., "Large-scale test of symmetric coldformed steel (CFS)-concrete composite beams with BTTST enhancement", Journal of Construction Steel Research, 67(4), 720-726, 2011.

[6] Hsu C.T.T, Punurai S., Punurai W. and Majdi Y., "New composite beams having coldformed steel joists and concrete slab", Engineering Structures, 71, 187-200, 2014.

[7] Kyvelou P., Gardner L. and Nethercot D.A., "Testing and analysis of composite coldformed steel and wood-based flooring systems", Journal of Structural Engineering, 143(11), 1-16, 2017

[8] GB/T 228.1-2010, "Metallic Materials-Tensile Testing-Part 1: Method of Test at Room Temperature", 2011, Beijing, Standard Press of China. (in Chinese)

[9] GB/T 50081-2002, Standard for test method of mechanical properties on ordinary concrete, 2002, Beijing, China Architecture \& Building Press. (in Chinese)

[10] Chien E. and Ritchie J.K., "Design and construction of composite floor systems", 1984, Ontario, Canadian Institute of Steel Construction.

[11] Ansys Inc, "Element reference", 2009b, Canonsburg, PA, Ansys Incorporation.

[12] Alhajri T.M., Tahir M.M., Azimi M., Mirza J., Lawan M. M. and Alenezi K.K., "Behavior of pre-cast U-shaped composite beam integrating cold-formed steel with ferro-cement slab", Thin-Walled Structures, 102, 18-29, 2016.

[13] Xu L., Sultana P. and Zhou X.H., "Flexural strength of cold-formed steel built-up box sections", Thin-Walled Structures. 47(6-7), 807-815, 2009.

[14] Hou H.T., Liu X., Qu B., Ma T.X., Liu H.N., Feng M.Y. and Zhang B., "Experimental evaluation of flexural behavior of composite beams with cast-in-place concrete slabs on precast prestressed concrete decks", Engineering Structures, 126, 405-416, 2016.

[15] Zhou X.H. and Jia Z.W., "Experimental study on flexural capacity of cold-formed steel joists and concrete composite floor", Journal of Building Structures, 7(31), 13-22, 2010. (in Chinese)

[16] Pinelopi K., Leroy G. and Nethercot D.A., "Design of composite cold-formed steel flooring systems", Structures, 12, 242-252, 2017.

[17] GB 50017-2017, Standard for design of steel structures, 2017, Beijing, China Architecture \& Building Press. (in Chinese). 